\title{
Partial utilization efficiencies of protein and methionine by barramundi (Lates calcarifer) in response to dietary methionine source and form.
}

David A. Poppi*1,2, Brett D. Glencross3.

1 The University of Queensland, Queensland Alliance for Agriculture and Food Innovation, Centre for Animal Science, St. Lucia, QLD 4067, Australia.

2 CSIRO Agriculture and Food, St. Lucia, QLD 4067, Australia.

3 Institute of Aquaculture, Stirling University, FK9 4LA Stirling, United Kingdom.

*Corresponding Author: david.poppi@uq.net.au

Postal Address: CSIRO Agriculture and Food, Building 80, Services Road, St. Lucia, QLD 4067, Australia.

Phone: +61 738335527

\begin{abstract}
An experiment was conducted with barramundi (Lates calcarifer) juveniles (initial weight $10.3 \mathrm{~g} \pm$ $0.3 \mathrm{~g}$ ) to examine the partial efficiency of utilization of methionine (Met) from both intact protein (fishmeal or lupin protein concentrate) and a crystalline DL-Met source. Fish were fed there allocated diet at one of three ration levels: Low ( $0.2 \mathrm{~g} / \mathrm{fish} /$ day), Moderate $(0.4 \mathrm{~g} / \mathrm{fish} /$ day $)$ and High $(0.8$ $\mathrm{g}$ /fish/day). Fish fed the fishmeal-based $\operatorname{diet}$ (Diet FML) at the highest ration level grew to an average weight of $37.3 \pm 0.46 \mathrm{~g}$ while those fed the Lupin Protein Concentrate (LPC)-based diet fortified with all EAA (Diet LPCM) at the highest ration level grew to $25.4 \pm 2.27 \mathrm{~g}$. The weight of the fish fed the LPC diet with no additional Met (Diet LPC) at the highest ration level declined over the course of the experiment resulting in a final weight of $9.2 \pm 0.88 \mathrm{~g}$, clearly demonstrating the impact of dietary Met deficiency. The partial efficiency of protein utilization was also significantly reduced when Met was limiting. Additionally, this parameter was lower than that of Met utilization in diets where Met was provided by intact protein, suggesting this was first limiting amino acid in these diets. The results suggested that the partial efficiency of both Met and protein utilization in diets where crystalline Met is the primary source of Met were significantly poorer than that from an intact protein source when Met is provided in excess.
\end{abstract}

This is the peer reviewed version of the following article: Poppi DA, Glencross BD. Partial utilization efficiencies of protein and methionine by barramundi (Lates calcarifer) in response to dietary methionine source and form. Aquaculture Research 2018;49:2518-2526, which has been published in final form at https://doi.org/10.1111/are.13714. This article may be used for non-commercial purposes in accordance With Wiley Terms and Conditions for self-archiving. 


\section{Introduction}

Methionine (Met) is typically the first limiting amino acid in non-cereal plant products such as soy- and lupin-derived protein meals (Lásztity et al., 2001; Takagi et al., 2001). In addition to its essential function as a component of protein, it plays a number of important roles in various metabolic processes including the initiation of protein synthesis (Drabkin and RajBhandary, 1998) and acting as a precursor for S-Adenosylmethionine (SAM), which is the principle methyl donor for a range of metabolic reactions (Stipanuk, 1986). Dietary deficiencies in this amino acid have been shown to cause cataracts in rainbow trout (Oncorhynchus mykiss) (Cowey et al., 1992), as well as stimulating the expression of a number of factors involved in the ubiquitin-proteosome and autophagy lysosomal proteolytic pathways (Belghit et al., 2014). Consequently, close attention must be paid to its inclusion in the diet of fish. Supplementation of DL-Met into diets with high levels of non-cereal plant meals has been reported to ameliorate some of the problems associated with the use of these protein sources (Mambrini et al., 1999; Takagi et al., 2001). It has, however, been shown that the utilization of amino acids by various fish species can differ significantly in response to the source of those nutrients, varying according to the protein source (Larsen et al., 2012) and whether the amino acids are proteinbound or crystalline (Chowdhury et al., 2013; Zarate and Lovell, 1997). It is thus equally as important to consider the proportion of dietary Met which is utilised by the fish in order to accurately determine the amount required in the diet for maximum growth.

It is also vital for the development of reliable nutrient utilization and fish performance models that more standardized assessments of response to varying nutrient supply and source are established. Partial (or marginal) efficiency of utilization (PEU), calculated using the slope of the linear relationship between the rate of intake and rate of retention of the nutrient of interest (Sawadogo et al., 1997), is a measurement of the efficiency with which an animal deposits into body tissue the proportion of a nutrient present in the diet which is in excess of the basal requirement (Rodehutscord and Pfeffer, 1999). By considering the maintenance demand, this measure of utilization accounts for some of the variability associated with differences in basal metabolism between studies, which can be influenced by several factors including environmental conditions or animal size (Archer et al., 1999; Bermudes et al., 2010; van den Borne et al., 2006), although the latter can also be corrected for with the use of a metabolic body weight exponent for the parameter of interest (Clarke and Johnston, 1999). In addition, analysis of efficiency based on the trend of the data over a range of nutrient intakes provides a more reliable interpretation of utilization as it is independent of the level of feed intake which can affect total efficiencies of utilization (NRC, 1981). While widespread in the assessment of the utilization of dietary protein and energy in fish (e.g. Bureau et al., 2006; Lupatsch et al., 2001; Rodehutscord and Pfeffer, 1999), partial efficiency of utilization has been applied sparingly to the assessment of individual amino acid utilization in these animals (Grisdale-Helland et al., 2011a; Grisdale-Helland et al., 2011b; Hauler and Carter, 2001; Hauler et al., 2007; Helland et al., 2010). 
The aim of this study was to determine the comparative utilization by barramundi of protein and Met in three diets, one being made using fishmeal as the main source of protein and two based on lupin protein concentrate (LPC): one limiting in Met, the other balanced for essential amino acids, using crystalline amino acid sources, to demonstrate any potential difference with which Met was utilised (or not) with reference to the form (L vs. DL-Met) and source of the dietary Met (proteinbound vs. crystalline). It was hypothesized that the efficiency of protein utilization would be significantly affected by the source of Met. The efficiency of Met utilization has not previously been investigated in this species, nor has the application of partial efficiency to individual amino acid utilization.

\section{Materials and Methods}

\subsection{Diets}

Three diets were formulated to the same digestible protein and energy densities: two based on a lupin protein concentrate (LPC) and the other containing fishmeal (FML) as the primary source of protein (Table 1). Digestible protein and energy contents were estimated based on data obtained from previous analyses (Glencross et al., 2017). Both of the LPC-based diets were fortified with crystalline amino acids in order to ensure all essential amino acids (EAA), with the exception of Met, were present in the diet well above estimated requirements. One of these diets (Diet LPCM) was additionally supplemented with DL-Met at a level well above requirement. The other LPC-based diet (Diet LPC) had no additional DL-Met and was substantially deficient in this EAA.

Water (30\% of mash dry weight) was added to the diet mash in order to form a dough. This dough was screw-pressed through a $4 \mathrm{~mm}$ diameter die before being dried at $70^{\circ} \mathrm{C}$ for 24 hours, air cooled and stored at $-20^{\circ} \mathrm{C}$.

\subsection{Fish Handling}

Eighteen 60L aquaria were stocked with fifteen (15) juvenile barramundi (Lates calcarifer) with an initial average weight of $10.3 \mathrm{~g}( \pm 0.2 \mathrm{~g})$, randomly assigned to duplicate tanks per treatment. The experimental tanks were set up with $\sim 2 \mathrm{~L} / \mathrm{min}$ flow of seawater (salinity $=35 \mathrm{PSU}$ ) with the intent of maintaining water temperature at around $30^{\circ} \mathrm{C}$ for the duration of the experiment. Fish were fed using a pair-fed restricted feeding approach with three different feed ration levels for each of the three diets (Low: 0.2; Moderate: 0.4; and High: $0.8 \mathrm{~g} /$ fish/day) split equally between two feeding events daily (0800 and 1500) five days a week; and once daily on weekends, for 28 days. 


\subsection{Sampling}

Five fish representative of the initial weight at the beginning of the experiment, and three fish from each tank at the conclusion were collected and euthanised by ice immersion. Fish from each tank were collectively minced. A sample of this mince was oven dried at $105^{\circ} \mathrm{C}$ for $24 \mathrm{~h}$ for determination of carcass dry matter and the remainder was freeze dried before analysis of sample dry matter, nitrogen, lipid, ash, amino acid and gross energy composition.

\subsection{Chemical analyses}

Diet and carcass compositional analyses were undertaken by the Chemistry Centre (East Perth, WA, Australia), a National Association of Testing Authorities accredited analytical service provider. Dry matter contents were determined by gravimetric analysis after oven drying at $105^{\circ} \mathrm{C}$ for $24 \mathrm{~h}$. Gross ash contents were determined based on mass change after sample combustion in a muffle furnace at $550^{\circ} \mathrm{C}$ for 12 hours. Total lipid contents were measured following extraction of the lipid portion of the samples using the method proposed by Folch et al. (1957). Total nitrogen was determined by Leco auto-analyzer (Leco Corp., St. Joseph, MI, USA) and used to calculate sample protein content based on $\mathrm{N}$ x 6.25. Gross energy was determined using adiabatic bomb calorimetry. Amino acid compositions were analysed by HPLC, following acid hydrolysis according to AOAC (1990).

\subsection{Protein and Methionine Utilization}

Body mass-independent (marginal) gains of Met and protein were calculated according to the following formula:

$$
\text { Marginal gain }=\text { Gain }_{\text {parameter }} / \mathrm{GMW}^{0.7} / t
$$

Where: Gain $_{\text {parameter }}$ is the Met or protein gained (g/fish); GMW is the geometric mean live-weight of the animal which, when transformed to an exponent of 0.7 , will herein be referred to as proteinmetabolism-body-weight (PBW); and $t$ is the duration of the experimental period.

Marginal intakes were calculated in the same way, with gain components of the equation substituted by intake as follows:

$$
\text { Marginal intake }=\text { Intake }_{\text {parameter }} / \mathrm{GMW}^{0.7} / t
$$

The slope derived from regression of the rate of marginal Met or protein deposition against the rate of marginal digestible Met or protein intake was taken to be the partial efficiency of its utilization 
(PEU) or marginal efficiency constant (NRC, 2011). A PBW exponent of 0.7, as defined for this species by Glencross and Bermudes (2011), was used in the calculations of marginal protein and Met intakes and retention in order to make these calculations independent of fish body size for future comparison (Glencross, 2008). Maintenance demands for DP and Met were defined as being the $x$ intercept at zero protein (or Met) gain.

\subsection{Statistical Analysis}

All figures contained within tables are means \pm S.E. Effects of nitrogen source, Met form and ration levels on performance parameters were determined by MANOVA in the R statistical package (manova; R Core Team, 2014). Significant differences were identified using Fisher's LSD test for planned comparisons, with a significance limit of $p<0.05$. Estimates of partial efficiency of utilization of protein and Met were determined following simple linear regression (lm; R Core Team, 2014). Replicate slopes (PEUs) were generated using a bootstrapping approach (Glencross and Bermudes, 2011) and compared by ANOVA (aov; R Core Team, 2014) with significant differences determined at the $p<0.05$ level using Tukey’s HSD test. Regression figures were created using Microsoft Excel.

\section{Results}

Fish fed the FML diet at the highest ration level gained the most weight over the course of the experimental period, growing to an average weight of $37.3( \pm 0.46) \mathrm{g}$ (Table 2) while the fastest growing fish fed the LPCM diet, also those at the highest ration level, grew to $25.4( \pm 2.27)$ g. The weight of the fish fed the LPC diet (LPC with no additional Met) at all ration levels declined in weight over the course of the experiment.

\subsection{Protein utilization}

The relationships between the PBW-adjusted rates of digestible protein intake and protein gain by fish fed each of the three diets at differing ration levels is presented in Figure 1. The partial efficiency of protein utilization by fish fed the fishmeal-based diet derived from this relationship was described by the linear equation: $y=0.6702 x-0.0088, R^{2}=0.98$; where $y$ denotes protein gain in $\mathrm{g} / \mathrm{kg}^{0.7} / \mathrm{day}$ and $x$ denotes digestible protein intake in $\mathrm{g} / \mathrm{kg}^{0.7} /$ day. Similarly, those of fish fed the Met supplemented and non-supplemented LPC-based diets were described by the linear equations: $y=0.3886 x-0.0008$, $R^{2}=0.96$ and $y=0.0588 x-0.4692, R^{2}=0.40$, respectively. The slope of these equations illustrates that the partial efficiency (coefficient) of protein utilization was highest for fish fed the fishmealbased diet (0.67), followed by that of the LPCM diet (0.39), while that of fish fed the LPC diet was only 0.06. All slopes were significantly different $(\mathrm{p}<0.05)$ from one another (Table 2$)$. 


\subsection{Methionine utilization}

The relationships between the PBW-adjusted rates of digestible Met intake and gain by fish in each of the treatments is presented in Figure 2. The partial efficiency of Met utilization for fish fed the fishmeal-based diet was described by the linear equation: $y=0.8944 x+0.0008, R^{2}=0.90$; where $y$ represents Met gain in $\mathrm{g} / \mathrm{kg}^{0.7} /$ day and $x$ represents digestible Met intake in $\mathrm{g} / \mathrm{kg}^{0.7} / \mathrm{day}$. That of fish fed the Met supplemented and non-supplemented LPC-based diets were described by the linear equations: $y=0.2556 x+0.0038, R^{2}=0.86$ and $y=0.3175 x-0.0173, R^{2}=0.52$, respectively. The partial efficiency (coefficients) of Met utilization of 0.26 and 0.32 derived from these equations for the LPCM and LPC diets respectively were not significantly different $(\mathrm{p}<0.05)$. The fishmeal based diet had a significantly higher $(p<0.05)$ partial efficiency (coefficient) of Met utilization of 0.90 (Fig. 2).

\section{Discussion}

Defining the efficiency with which an animal utilizes specific dietary components, such as individual amino acids, is an important element of accurate nutrient utilisation and fish performance models. Several factors can influence this process in fish, including animal size and water temperature, as well as the source and form of the nutrient in question. This study aimed to define the influence of the latter two factors on the efficiency of utilization of Met in barramundi.

In the present study, it was observed that the source of dietary Met had a significant effect on the efficiency with which this amino acid is used by barramundi. The partial efficiencies of both protein and Met utilization in diets where the majority of dietary Met was provided by crystalline DL-Met, were significantly poorer than those from the intact protein source, fishmeal. Similar observations of the differential utilization of amino acids from different sources have been reported by several authors (Zarate and Lovell, 1997; Rønnestad et al., 2000; Williams et al., 2001; Webb and Gatlin, 2003). Rainbow trout fed a diet containing lysine from flash-dried blood meal, for example, were observed by El-Haroun and Bureau (2007) to exhibit significantly greater weight gain and nitrogen retention, in comparison to those fed a diet where the lysine was supplied by L-lysine $\mathrm{HCl}$. This trend is likely a reflection of the more rapid passage of free amino acids through the digestive system and their subsequent earlier absorption in comparison to those bound in proteins (Zarate et al., 1999). The disparity in the timing of individual amino acid absorption results in disruption of the balance of amino acids required for optimal protein synthesis which Ambardekar et al. (2009) suggested may lead to catabolism of these amino acids and consequent reduction in the utilization efficiency. Reduction in utilization of free amino acids has previously been suggested to be influenced by leaching of these unbound nutrients into the water column before ingestion by the animal (Peres and Oliva-Teles, 2005), although this is unlikely to be a major issue in this case as feed was consumed almost immediately upon contact with the water. Both of these factors can be overcome, however, 
through coating of the crystalline amino acids with substances such as zein, carboxymethyl cellulose or $k$-carrageenan (Alam et al., 2004; Millamena et al., 1996). This has the combined effect of more effectively binding the amino acids in the dietary matrix, thus preventing their premature loss, as well as requiring more prolonged digestion, thereby slowing the passage of the amino acid through the digestive system and ensuring absorption of these nutrients occurs in parallel with those derived from the hydrolysis of whole proteins in the stomach. This could also explain the differences in the pattern of response in the rate of Met gain to increasing digestible Met intake between the LPCM and FML diets in the present study, despite the fact that they both contained dietary Met levels well in excess of the requirement. A recent study (Poppi et al., 2017) concluded the minimum Met requirement for maximising growth in barramundi to be $10.5 \mathrm{~g} / \mathrm{kg}$ DM (1.8\% of protein) in a diet containing $59 \%$ crude protein and $6.6 \mathrm{~g} / \mathrm{kg}$ cystine (Cys) (equal to $17.1 \mathrm{~g} / \mathrm{kg}$ dry diet (2.9\% of protein) total sulphur amino acids (TSAA), (Met+Cys)). The Met-supplemented LPC diet in this study (Diet LPCM) had a dietary Met level of $23.7 \mathrm{~g} / \mathrm{kg} \mathrm{DM}$ (4.12\% of protein), more than twice the Met-specific requirement, yet fish in this treatment did not perform as well as those in the FML treatment, which had a dietary Met content of only $18.2 \mathrm{~g} / \mathrm{kg} \mathrm{DM}$ (although this is also well above the requirement). Both diets had a gross excess of Cys, making them both also considerably in excess of the TSAA requirement. The reduced performance of the fish in the LPCM treatment may be an indication that a significant proportion of the crystalline DL-Met (which made up $75 \%$ of the total Met in the diet) passed through the digestive system and was absorbed and catabolized before being incorporated into tissue protein. This may also be supported by the shape of the best-fitting response model. The relationship between the rate of Met gain and rate of digestible Met intake in the fishmeal based diet (Diet FML) was best described by a non-linear ( $2^{\text {nd }}$ order polynomial) equation with an $R^{2}$ value (data not shown) of 0.992 (compared with an $R^{2}$ value of 0.897 for the reported linear relationship required for calculation of the partial efficiency). That of fish fed the Met-supplemented LPC-based diet, however, was significantly linear, suggesting the level of Met required for maximum growth had not been reached, despite being well in excess of the requirement on a dietary content basis.

Differences between protein and Met-specific partial efficiencies in the LPCM diet confirm that Met was not the first limiting amino acid in this diet. The coefficient of partial efficiency of Met utilization of fish fed the fishmeal-based diet was much higher (0.89) than that of protein utilization (0.67), suggesting that dietary Met level was the main driver of Met retention (i.e. protein deposition). This would suggest that Met was the first limiting amino acid in these diets, which seems to agree with the assertion of Nankervis and Southgate (2006) that Met is first limiting in fishmeal to barramundi. On the other hand, fish fed the Met-supplemented LPC-based diet exhibited a much lower coefficient of partial efficiency of Met utilization than that of total protein $(0.26$ compared with 0.39 for protein utilization), suggesting a proportion of dietary Met was used for processes other than protein deposition, possibly catabolized for energy or excreted, and that protein synthesis was constrained by a factor other than Met inclusion. 
As Met became increasingly limiting in the diet (Diets LPCM vs. LPC), the ability of the fish to use the dietary protein was significantly compromised, most likely due to an imbalance of the EAA. It has been theorized that a defined balance of dietary amino acids is required for optimal protein synthesis (Wilson, 2002), due to the genetically predetermined nature of the amino acid composition of specific proteins (NRC, 2011). According to this theory, when amino acids are not provided in the diet in the correct proportions, those which are in surplus are mostly either catabolized for energy or excreted as ammonia (Trushenski et al., 2006; Hart et al., 2009). This was apparent in the present study where, despite the diets having similar digestible protein contents, fish fed Diet LPC (LPCbased diet with no additional Met) exhibited a significantly lower efficiency of protein utilization than those fed the Met-supplemented diet. The deficiency of Met, in comparison to the proposed ideal amino acid balance (based on the whole-body composition of the animal), in that diet meant that a large proportion of the amino acids derived from the dietary protein were unable to be utilised for protein synthesis and deposition. Where an excess of Met was provided (Diet LPCM), a greater proportion of the available amino acids was utilised, increasing the partial efficiency of utilization of the ingested protein.

While fish fed Diet LPC (LPC-based diet with no additional Met), exhibited a poor efficiency of protein utilization (a coefficient of 0.06), the efficiency of Met utilization was considerably higher (0.32), suggesting Met was the first limiting amino acid in this case and was the limiting constraint to the rate of protein synthesis. It would be expected, then, that the majority of Met ingested from this diet would be incorporated into body protein. This, however, was not the case. Only $32 \%$ of the dietary Met was deposited in the protein of these fish (based on the assumption that Met gain is a reflection of deposition in the protein), compared to $89 \%$ of that provided by the fishmeal-based diet. This disparity suggests one of two things: either the Met in this diet is not being released during digestion (or is in a form which is unavailable to the animal) or that a proportion of it is being catabolized. The protein in lupin protein concentrates, such as that used in this study, was found by Glencross (2011) to be highly (98.6\%) digestible by barramundi. However, Glencross et al. (2007) found that the processing method (in that case, drying technique) can significantly affect the availability of this digested protein, so while it is efficiently digested, it may be in a form which is not completely available for protein synthesis. A more likely reason is that, at such a low inclusion level, any catabolism of amino acids, whether for energy or through inevitable catabolism (NRC, 2011), would have a significant impact on the amount of Met available for deposition. It is not known what contribution non-essential amino acids (NEAA) or excess EAAs play in fulfilling this requirement for energy, however, it was suggested by Encarnação et al. (2006) that NEAAs may not preferentially spare EAAs when the rate of amino acid catabolism is high, a situation which was likely the case in fish fed this diet, as illustrated by the overall loss of protein across all dietary intake levels. Alternatively, perhaps other roles of Met, such as production of SAM or taurine, are prioritized over synthesis of protein, although there is no direct evidence of this. 
The form of Met too has been suggested in the past to have an influence on utilization of this amino acid by fish. Only the L- isomers of amino acids are able to be utilised directly in protein synthesis, however, it is generally accepted that most animals (including fish) utilise dietary D- and Lamino acids with similar efficiencies (NRC, 2011), with Sveier et al., (2001) finding that D-Met significantly improved protein retention in Atlantic salmon (Salmo salar) compared to L-Met and Kim et al., (1992) observing equivalent utilization of both forms for weight gain in rainbow trout (Oncorhynchus mykiss) (although D-Met was used less efficiently for protein gain in that study). One of the aims of the present study was to compare the utilization efficiencies of L and DL Met by comparing the response to the Met-supplemented LPC-based diet (i.e. DL-Met) with that of fish fed the fishmeal-based diet (L-Met). In addition to the interpretation surrounding response to the form of Met (crystalline vs. protein bound), the greater PEU of Met in response to Diet FML, compared with that Diet LPCM could be interpreted to mean that the L form was being used more efficiently than DL-Met for Met (protein) gain. This interpretation, however, could be confounded by the fact that Met is probably the first limiting amino acid in fishmeal, meaning increases in its supply will have more dramatic effects on deposition, but appears to be in excess in Diet LPCM, as previously discussed. As well, it is difficult to say whether the observed response was due to the form of the Met (L vs. DL) or the source (protein bound vs. crystalline) since the DL-Met was not pre-bound.

The failure to derive a positive maintenance requirement value for Met from the utilization efficiency relationship for fish fed the fishmeal and Met-supplemented LPC diets, the best performing treatments, was unexpected. This is particularly surprising for Met, given it is an EAA and is thus clearly required to be provided in the diet. In fact, Mambrini and Kaushik (1995) reported relatively high maintenance requirements for sulphur amino acids by rainbow trout. The limitations of using this method to derive maintenance requirements have previously been identified, with Bureau et al. (2006) finding it underestimated maintenance energy requirements of rainbow trout compared with a factorial approach (although it cannot be said whether the factorial approach is actually more accurate). Had any error been corrected, allowing minor adjustment to the slope of the relationship, however, it seems likely that derived maintenance requirements would nevertheless have been negligible as was seen for the response to the LPC diet. The derived crude protein requirements were similarly implausibly low, highlighting the complexities of using this method of estimation.

\section{Conclusion}

Methionine appeared to be the first limiting amino acid in both the fishmeal and unsupplemented LPC-based diets. It was also apparent that dietary Met source impacted protein utilization efficiency when Met was provided in excess, with partial efficiencies of protein utilization being significantly greater in fish fed a diet where Met was provided from an intact source of protein (fishmeal) than where crystalline DL-Met was the primary source. This relationship could also be interpreted to 
suggest that L-Met was used more efficiently for protein retention than DL-Met, however, it was not possible to separate the effect of Met source (protein bound vs. crystalline) and form (L- vs. DL-Met).

\section{References}

Alam, M., Teshima, S., Koshio, S., Ishikawa, M., 2004. Effects of supplementation of coated crystalline amino acids on growth performance and body composition of juvenile kuruma shrimp Marsupenaeus japonicus. Aquaculture nutrition. 10, 309-316.

Ambardekar, A.A., Reigh, R.C., Williams, M.B., 2009. Absorption of amino acids from intact dietary proteins and purified amino acid supplements follows different time-courses in channel catfish (Ictalurus punctatus). Aquaculture. 291, 179-187.

AOAC, 1990. Official Methods of Analysis of the Association of Official Analytical Chemists, 15 ed. Association of Official Analytical Chemists, Washington, DC, USA.

Archer, J.A., Richardson, E.C., Herd, R.M., Arthur, P.F., 1999. Potential for selection to improve efficiency of feed use in beef cattle: a review. Australian Journal of Agricultural Research 50, 147-162.

Belghit, I., Skiba-Cassy, S., Geurden, I., Dias, K., Surget, A., Kaushik, S., Panserat, S., Seiliez, I., 2014. Dietary methionine availability affects the main factors involved in muscle protein turnover in rainbow trout (Oncorhynchus mykiss). British Journal of Nutrition, 1-11.

Bermudes, M., Glencross, B., Austen, K., Hawkins, W., 2010. The effects of temperature and size on the growth, energy budget and waste outputs of barramundi (Lates calcarifer). Aquaculture 306, 160-166.

Bureau, D., Harris, A., Cho, C., 1999. Apparent digestibility of rendered animal protein ingredients for rainbow trout (Oncorhynchus mykiss). Aquaculture. 180, 345-358.

Bureau, D.P., Hua, K., Cho, C.Y., 2006. Effect of feeding level on growth and nutrient deposition in rainbow trout (Oncorhynchus mykiss Walbaum) growing from 150 to $600 \mathrm{~g}$. Aquaculture Research 37, 1090-1098.

Chowdhury, K., Iñiguez, K.P., Lange, C.F., Osborne, V., Lemme, A., Bureau, D.P., 2013. Bioavailability of arginine from Indian mustard protein concentrate and meal compared with that of a soy protein concentrate in rainbow trout (Oncorhynchus mykiss). Aquaculture Research 46, 2092-2103.

Clarke, A., Johnston, N.M., 1999. Scaling of metabolic rate with body mass and temperature in teleost fish. Journal of Animal Ecology. 68, 893-905.

Cowey, C.B., Cho, C.Y., Sivak, J.G., Weerheim, J.A., Stuart, D.D., 1992. Methionine intake in rainbow trout (Oncorhynchus mykiss), relationship to cataract formation and the metabolism of methionine. The Journal of nutrition 122, 1154-1163.

Drabkin, H.J., RajBhandary, U.L., 1998. Initiation of protein synthesis in mammalian cells with codons other than AUG and amino acids other than methionine. Molecular and cellular biology $18,5140-5147$.

El-Haroun, E.R., Bureau, D.P., 2007. Comparison of the bioavailability of lysine in blood meals of various origins to that of l-lysine HCL for rainbow trout (Oncorhynchus mykiss). Aquaculture. 262, 402-409.

Encarnação, P., de Lange, C., Bureau, D.P., 2006. Diet energy source affects lysine utilization for protein deposition in rainbow trout (Oncorhynchus mykiss). Aquaculture. 261, 1371-1381.

Folch, J., Lees, M., Sloane-Stanley, G., 1957. A simple method for the isolation and purification of total lipids from animal tissues. J. biol. Chem. 226, 497-509.

Glencross, B.D., Hawkins, W.E., Evans, D., McCafferty, P., Dods, K., Sipsas, S. 2007. Heat damage during some drying techniques affects nutrient utilisation, but not digestibility of lupin protein concentrates fed to rainbow trout (Oncorhynchus mykiss). Aquaculture 265, $218-229$.

Glencross, B.D., 2008. A factorial growth and feed utilization model for barramundi, Lates calcarifer, based on Australian production conditions. Aquaculture Nutrition 14, 360-373.

Glencross, B., 2011. A comparison of the digestibility of diets and ingredients fed to rainbow trout (Oncorhynchus mykiss) or barramundi (Lates calcarifer) - the potential for inference of digestibility values among species. Aquaculture Nutrition. 17, 207-215. 
Glencross, B.D., Bermudes, M., 2011. Effect of high water temperatures on the allometric scaling effects of energy and protein starvation losses in juvenile barramundi (Lates calcarifer). Comparative Biochemistry and Physiology - Part A 159, 167-174.

Glencross, B., Blyth, D., Cheers, S., Bourne, N., Wade, N., Irvin, S., 2017. A compendium of raw material digestibilities for barramundi, Lates calcarifer. Aquaculture Nutrition. 23, 1055-1064.

Grisdale-Helland, B., Hatlen, B., Mundheim, H., Helland, S.J., 2011. Dietary lysine requirement and efficiency of lysine utilization for growth of Atlantic cod. Aquaculture 315, 260-268.

Grisdale-Helland, B., Gatlin, D.M., Corrent, E., Helland, S.J., 2011. The minimum dietary lysine requirement, maintenance requirement and efficiency of lysine utilization for growth of Atlantic salmon smolts. Aquaculture Research 42, 1509-1529.

Hart, S.D., Brown, B.J., Gould, N.L., Robar, M.L., Witt, E.M., Brown, P.B., 2009. Predicting the optimal dietary essential amino acid profile for growth of juvenile yellow perch with whole body amino acid concentrations. Aquaculture Nutrition. 16, 248-253.

Hauler, R.C., Carter, C.G., 2001. Lysine deposition responds linearly to marginal lysine intake in Atlantic salmon (Salmo salar L.) parr. Aquaculture Research 32, 147-156.

Hauler, R.C., Carter, C.G., Edwards, S.J., 2007. Feeding regime does not influence lysine utilization by Atlantic salmon, Salmo salar L., parr. Aquaculture 273, 545-555.

Helland, S.J., Hatlen, B., Grisdale-Helland, B., 2010. Energy, protein and amino acid requirements for maintenance and efficiency of utilization for growth of Atlantic salmon post-smolts determined using increasing ration levels. Aquaculture 305, 150-158.

Kim, K.-I., Kayes, T.B., Amundson, C.H., 1992. Requirements for sulfur amino acids and utilization of D-methionine by rainbow trout (Oncorhynchus mykiss). Aquaculture. 101, 95-103.

Larsen, B.K., Dalsgaard, J., Pedersen, P.B., 2012. Effects of plant proteins on postprandial, free plasma amino acid concentrations in rainbow trout (Oncorhynchus mykiss). Aquaculture 326, 90 98.

Lásztity, R., Khalil, M.M., Haraszi, R., Baticz, O., Tömösközi, S., 2001. Isolation, functional properties and potential use of protein preparations from lupin. Food / Nahrung 45, 396-398.

Lupatsch, I., Kissil, G.W., Sklan, D., Pfeffer, E., 1998. Energy and protein requirements for maintenance and growth in gilthead seabream (Sparus aurata L.). Aquaculture Nutrition 4, 165 173.

Lupatsch, I., Kissil, G.W., Sklan, D., Pfeffer, E., 2001. Effects of varying dietary protein and energy supply on growth, body composition and protein utilization in gilthead seabream (Sparus aurata L.). Aquaculture Nutrition 7, 71-80.

Mambrini, M., Kaushik, S.J., 1995. Effect of temperature on sulphur amino acid requirements for maintenance and growth of juvenile rainbow trout. in: Nunes, A.F., Portugal, A.V., Costa, J.P., Ribiero, J.R. (Eds.), Protein metabolism and nutrition : proceedings of the 7th International Symposium on Protein Metabolism and Nutrition, Vale de Santarem, Portugal, 24-27 May 1995. Santarem, Portugal, pp. 117-122.

Mambrini, M., Roem, A.J., Carvedi, J., Lalles, J., Kaushik, S., 1999. Effects of replacing fish meal with soy protein concentrate and of DL-methionine supplementation in high-energy, extruded diets on the growth and nutrient utilization of rainbow trout, Oncorhynchus mykiss. Journal of animal science 77, 2990-2999.

Millamena, O.M., Bautista-Teruel, M.N., Kanazawa, A., 1996. Methionine requirement of juvenile tiger shrimp Penaeus monodon Fabricius. Aquaculture. 143, 403-410.

Nankervis, L., Southgate, P.C., 2006. An integrated assessment of gross marine protein sources used in formulated microbound diets for barramundi (Lates calcarifer) larvae. Aquaculture. 257, 453464.

NRC, 2011. Nutrient requirements of fish and shrimp. The National Academies Press Washington, DC.

NRC, 1981. Nutritional Efficiency, Effect of Environment on Nutrient Requirements of Domestic Animals. National Academy Press. Washington, D.C., USA, 52.

Peres, H., Oliva-Teles, A., 2005. The effect of dietary protein replacement by crystalline amino acid on growth and nitrogen utilization of turbot Scophthalmus maximus juveniles. Aquaculture. 250, 755-764. 
Poppi, D.A., Moore, S.S., Glencross, B.D., 2017. Redefining the requirement for total sulfur amino acids in the diet of barramundi (Lates calcarifer) including assessment of the cystine replacement value. Aquaculture. 471, 213-222.

Rodehutscord, M., Pfeffer, E., 1999. Maintenance requirement for digestible energy and efficiency of utilization of digestible energy for retention in rainbow trout, Oncorhynchus mykiss. Aquaculture 179, 95-107.

Rønnestad, I., Conceição, L.E., Aragão, C., Dinis, M.T., 2000. Free amino acids are absorbed faster and assimilated more efficiently than protein in postlarval Senegal sole (Solea senegalensis). The Journal of nutrition. 130, 2809-2812.

Sawadogo, M., Piva, A., Panciroli, A., Meola, E., Mordenti, A., Seve, B., 1997. Marginal efficiency of free or protected crystalline L-tryptophan for tryptophan and protein accretion in early-weaned pigs. Journal of animal science 75, 1561-1568.

Stipanuk, M.H., 1986. Metabolism of sulfur-containing amino acids. Annual review of nutrition 6, 179-209.

Sveier, H., Nordas, H., Berge, G., Lied, E., 2001. Dietary inclusion of crystalline D-and Lmethionine: effects on growth, feed and protein utilization, and digestibility in small and large Atlantic salmon (Salmon salar L.). Aquaculture Nutrition. 7, 169-181.

Takagi, S., Shimeno, S., Hosokawa, H., Ukawa, M., 2001. Effect of lysine and methionine supplementation to a soy protein concentrate diet for red sea bream Pagrus major. Fisheries Science 67, 1088-1096.

Trushenski, J.T., Kasper, C.S., Kohler, C.C., 2006. Challenges and Opportunities in Finfish Nutrition. North American Journal of Aquaculture. 68, 122-140.

van den Borne, J.J., Verdonk, J.M., Schrama, J.W., Gerrits, W.J., 2006. Reviewing the low efficiency of protein utilization in heavy preruminant calves-a reductionist approach. Reproduction Nutrition Development 46, 121-137.

Webb Jr, K., Gatlin III, D., 2003. Effects of dietary protein level and form on production characteristics and ammonia excretion of red drum Sciaenops ocellatus. Aquaculture. 225, 17-26.

Williams, K., Barlow, C., Rodgers, L., 2001. Efficacy of crystalline and protein-bound amino acids for amino acid enrichment of diets for barramundi/Asian seabass (Lates calcarifer Bloch). Aquaculture Research. 32, 415-429.

Wilson, R.P., 2002. Amino acids and proteins. in: Halver, J.E., Hardy, R.W. (Eds.), Fish nutrition. Academic Press, San Diego, CA, USA., pp. 144-175.

Zarate, D., Lovell, R., Payne, D., 1999. Effects of feeding frequency and rate of stomach evacuation on utilization of dietary free and protein-bound lysine for growth by channel catfish Ictalurus punctatus. Aquaculture Nutrition. 5, 17-22.

Zarate, D.D., Lovell, R.T., 1997. Free lysine (1-lysine- HCl) is utilized for growth less efficiently than protein-bound lysine (soybean meal) in practical diets by young channel catfish (Ictalurus punctatus). Aquaculture 159, 87-100. 
Table 1. Formulations and analysed compositions of the experimental diets.

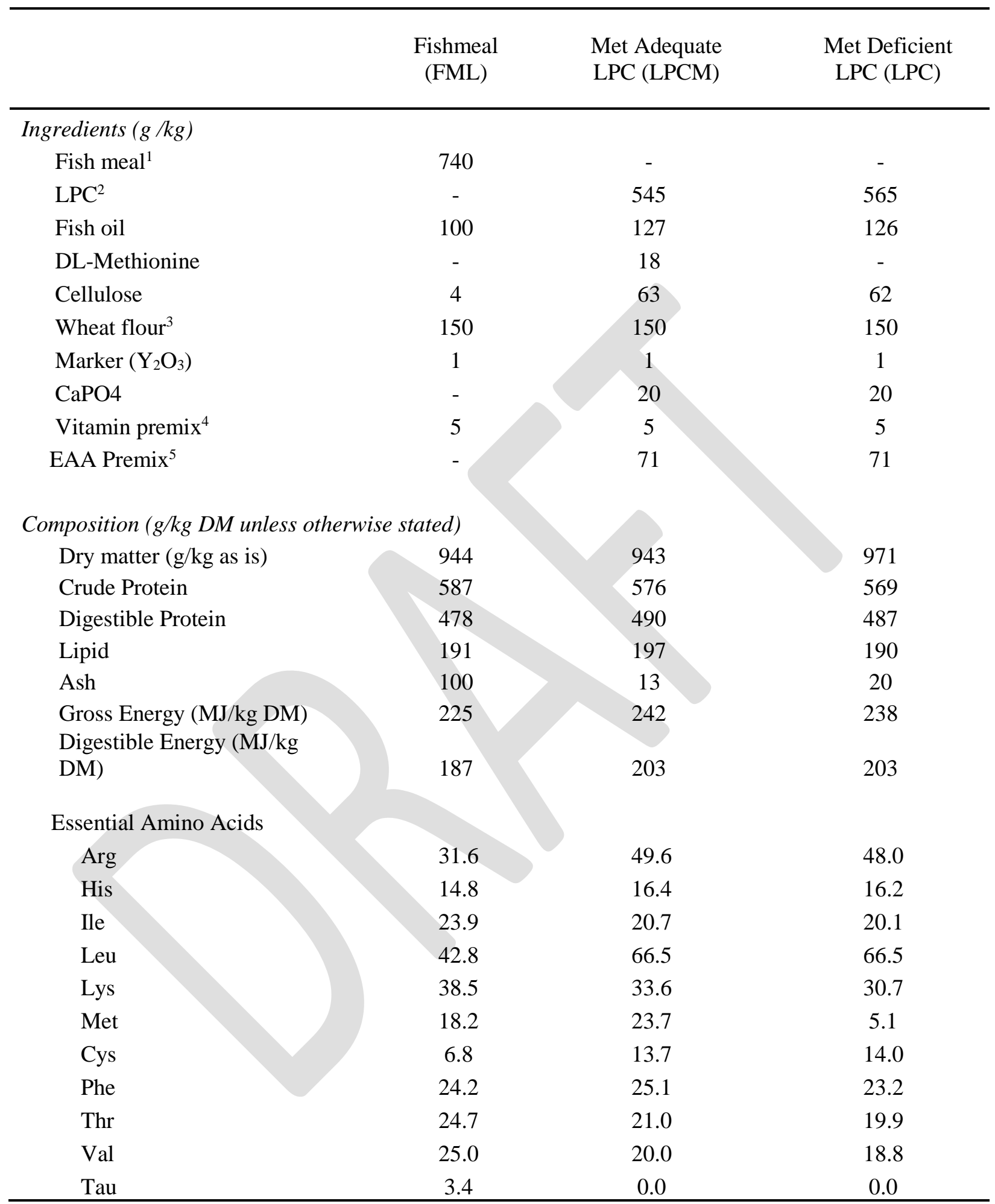

${ }^{1}$ LPC: L. luteus protein concentrate: Department of Agriculture and Food, South Perth, WA, Australia.

${ }^{2}$ Fishmeal: Chilean anchovy meal, Skretting Australia, Cambridge, TAS, Australia.

${ }^{3}$ Wheat Flour: Manildra, Auburn, NSW, Australia.

${ }^{4}$ Vitamin and mineral premix includes (IU/kg or g/kg of premix): retinol, $2.5 \mathrm{MIU}$; cholecalciferol, $0.25 \mathrm{MIU} ; \alpha$ tocopherol,16.7 g; Vitamin K3,1.7 g; thiamin, $2.5 \mathrm{~g}$; riboflavin, $4.2 \mathrm{~g}$; niacin, $25 \mathrm{~g}$; pantothenic acid, 8.3; pyridoxine, $2.0 \mathrm{~g}$; folate, 0.8; Vitamin B12, $0.005 \mathrm{~g}$; Biotin, $0.17 \mathrm{~g}$; Vitamin C, $75 \mathrm{~g}$; Choline,166.7 g; Inositol, $58.3 \mathrm{~g}$; Ethoxyquin, $20.8 \mathrm{~g}$; Copper, $2.5 \mathrm{~g}$; Ferrous iron, $10.0 \mathrm{~g}$; Magnesium, $16.6 \mathrm{~g}$; Manganese, $15.0 \mathrm{~g}$; Zinc, $25.0 \mathrm{~g}$. ${ }^{5}$ Essential amino acid premix consisting of $(\mathrm{g} / \mathrm{kg})$ : L-Isoleucine, $28.2 \mathrm{~g}$; L-Valine, $70.4 \mathrm{~g}$; L-Histidine, $70.4 \mathrm{~g}$; LLeucine, 422.5; L-Phenylalanine, 56.3; L-Threonine, 84.5; L-Lysine, 267.6. 


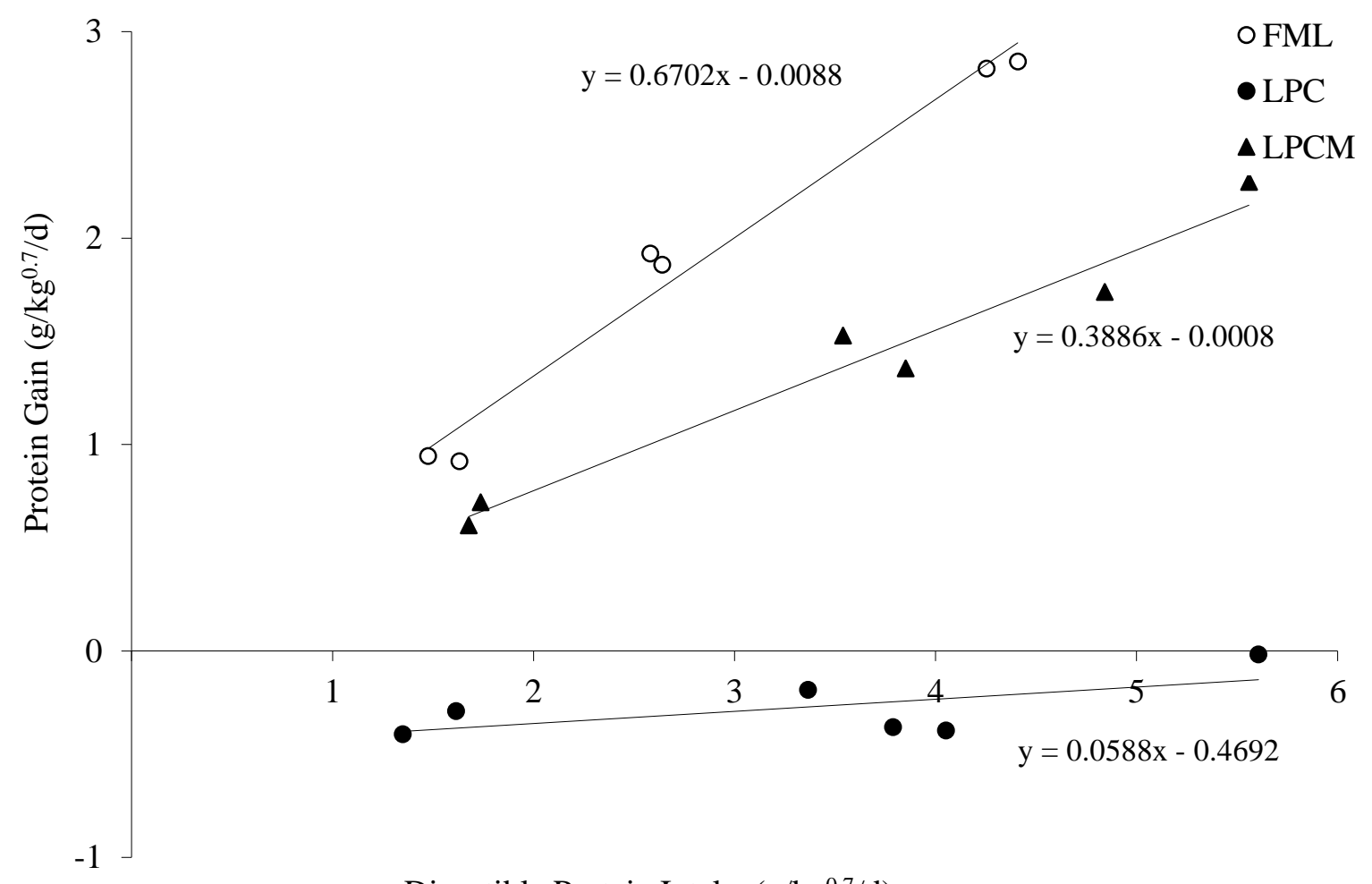

Digestible Protein Intake (g/kg0.7/d)

Figure 1. Rate of protein gain in response to rate of protein intake by barramundi (Lates calcarifer) fed diets containing either fishmeal (FML) or DL-Methionine supplemented (LPCM) or nonsupplemented (LPC) lupin protein concentrate as the primary source of protein. 


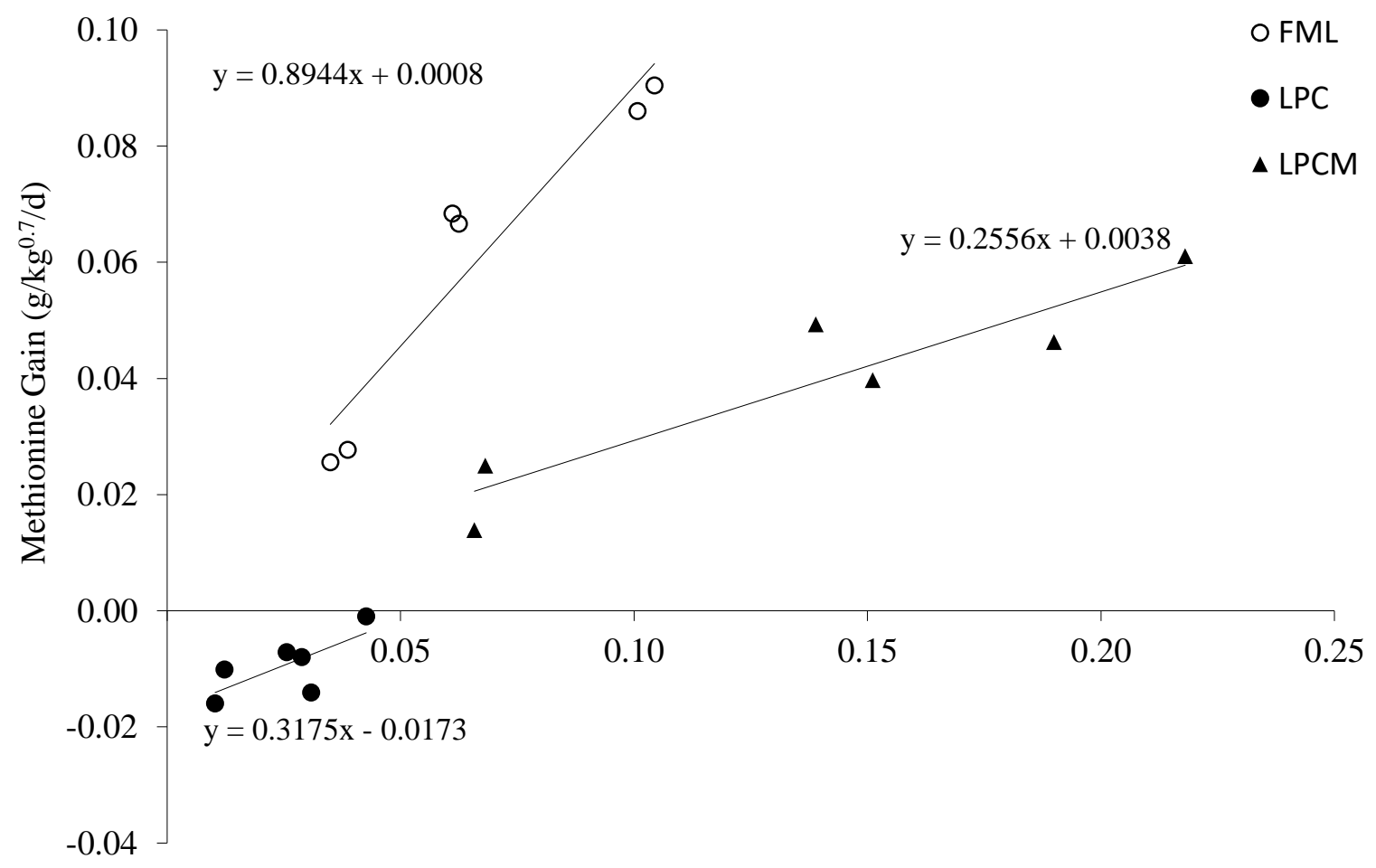

Digestible Methionine Intake ( $\left./ \mathrm{kg}^{0.7} / \mathrm{d}\right)$

Figure 2. Rate of methionine gain in response to rate of methionine intake by barramundi (Lates calcarifer) fed diets containing either fishmeal (FML) or DL-Methionine supplemented (LPCM) or non-supplemented (LPC) lupin protein concentrate as the primary source of protein. 
Table 2. Response of juvenile barramundi (Lates calcarifer) to variable dietary methionine provided by either fishmeal (FML); or DL-Methioninesupplemented (LPCM) or non-supplemented (LPC) lupin protein concentrate fed at three ration levels ${ }^{1}$.

\begin{tabular}{|c|c|c|c|c|c|c|c|c|c|}
\hline $\begin{array}{c}\text { Initial } \\
\text { Fish }\end{array}$ & & LPC & & & LPCM & & & FML & \\
\hline Feeding Ration $^{2}$ & Low & Mod & High & Low & Mod & High & Low & Mod & High \\
\hline \multicolumn{10}{|c|}{ Fish Performance Criteria (g/fish unless otherwise indicated) } \\
\hline Initial weight & 10.5 & 10.0 & 10.5 & 10.4 & 10.4 & 10.3 & 10.3 & 10.2 & 10.5 \\
\hline Final weight & $8.7^{\mathrm{a}}$ & $8.8^{\mathrm{a}}$ & $9.2^{\mathrm{a}}$ & $14.0^{\mathrm{b}}$ & $21.2^{\mathrm{d}}$ & $25.5^{\mathrm{e}}$ & $17.5^{\mathrm{c}}$ & $25.6^{\mathrm{e}}$ & $37.3^{\mathrm{f}}$ \\
\hline Feed intake (g/fish/day) & $2.9^{\mathrm{a}}$ & $6.6^{\mathrm{bc}}$ & $9.8^{\mathrm{d}}$ & $4.1^{\mathrm{a}}$ & $10.3^{\mathrm{d}}$ & $15.4^{\mathrm{e}}$ & $4.6^{\mathrm{ab}}$ & $8.7^{\mathrm{cd}}$ & $16.6^{\mathrm{e}}$ \\
\hline Gain & $-1.8^{\mathrm{a}}$ & $-1.2^{\mathrm{a}}$ & $-1.3^{\mathrm{a}}$ & $3.6^{\mathrm{b}}$ & $10.8^{\mathrm{d}}$ & $15.1^{\mathrm{e}}$ & $7.2^{\mathrm{c}}$ & $15.4^{\mathrm{e}}$ & $26.8^{f}$ \\
\hline $\mathrm{FCR}^{3}$ & -1.64 & -5.66 & -7.69 & 1.13 & 0.95 & 1.02 & 0.63 & 0.57 & 0.62 \\
\hline \multicolumn{10}{|c|}{ Whole Body Proximate Composition ( $\mathrm{g} / \mathrm{kg}$ as-is unless otherwise indicated) } \\
\hline Dry Matter & 260 & 270 & 270 & 300 & 290 & 280 & 270 & 280 & 290 \\
\hline Protein & 156.0 & 162.0 & 164.7 & 183.0 & 179.8 & 184.8 & 164.7 & 176.4 & 176.9 \\
\hline Energy $(\mathrm{MJ} / \mathrm{kg})$ & 20.4 & 20.6 & 21.5 & 23.7 & 24.1 & 22.0 & 21.1 & 23.1 & 22.1 \\
\hline Lipid & 70.2 & 72.9 & 81.0 & 90.0 & 87.0 & 84.0 & 67.5 & 72.8 & 78.3 \\
\hline Methionine & 4.1 & 4.5 & 4.5 & 5.3 & 5.3 & 5.1 & 4.8 & 5.9 & 5.4 \\
\hline \multicolumn{10}{|l|}{ Partial Utilization Efficiencies } \\
\hline Protein & & $0.06( \pm 0.01)^{\mathrm{a}}$ & & & $0.39( \pm 0.01$ & & & $0.67( \pm 0.01)^{\mathrm{c}}$ & \\
\hline Methionine & & $0.32( \pm 0.04)^{\mathrm{a}}$ & & & $0.26( \pm 0.01$ & & & $0.89( \pm 0.03)^{b}$ & \\
\hline \multicolumn{10}{|l|}{ Maintenance Demand ${ }^{4}$} \\
\hline Protein & & & & & -0.002 & & & -0.013 & \\
\hline Methionine & & 0.054 & & & -0.015 & & & -0.001 & \\
\hline
\end{tabular}

${ }^{1}$ Values sharing a common superscript letter are not significantly different $(\mathrm{p}<0.05)$.

${ }^{2}$ Feeding ration: Low: 0.2g/fish/day; Moderate (Mod): 0.4g/fish/day; High: $0.8 \mathrm{~g} / \mathrm{fish} / \mathrm{day}$.

${ }^{3}$ FCR: feed conversion ratio (g dry feed/g wet weight gain).

${ }^{4}$ Maintenance demand $\left(\mathrm{g} / \mathrm{kg}^{0.7} / \mathrm{d}\right)$ determined by extrapolation of the linear relationship to $0=b(x)+a$ 